Article

\title{
Green Innovation Risk Identification of the Manufacturing Industry under Global Value Chain Based on Grounded Theory
}

\author{
Yingying Sun ${ }^{1}$, Lei $\mathrm{Wu}^{1, *}$ and Shi Yin ${ }^{2}$ (D) \\ 1 School of Economics and Management, Harbin Engineering University, Harbin 150001, China; \\ sunyingying2019@126.com \\ 2 College of Economics and Management, Hebei Agricultural University, Baoding 071001, China; \\ shyshi0314@163.com \\ * Correspondence: wulei@hrbeu.edu.cn
}

Received: 13 August 2020; Accepted: 13 November 2020; Published: 9 December 2020

\begin{abstract}
Green innovation in the manufacturing industry has been widely recognized. Although green innovation can create economic, social, and ecological value, it is also a high-risk activity. We must facilitate and protect the value of green innovation through scientific and systematic management of the risks generated in the process of innovation. The primary task of risk management is risk identification. Therefore, based on the perspective of the global value chain, this paper identifies the risk of green innovation in the manufacturing industry using the research method of grounded theory. By examining the interview records of 25 manufacturing enterprise executives, we summarize and identify the four major risks and 31 risk factors of green innovation. The empirical results of this paper are as follows: (1) the green innovation risks of the manufacturing industry under the global value chain include green R\&D risks under the global value chain; manufacturing risks under the global value chain; marketing risks under the global value chain; service risks under the global value chain. (2) Green R\&D risks under the global value chain include seven risk factors; green manufacturing risks under the global value chain include 10 risk factors; green marketing risks under the global value chain include nine risk factors; green service risks under the global value chain include five risk factors.
\end{abstract}

Keywords: manufacturing industry; green innovation; risk identification; influence factor; grounded theory

\section{Introduction}

Since the 1980s, the accelerated development of production and trade globalization has become a significant feature of the world economy. Globalization has accelerated the international movement of the production of elements, such as commodities, capital, and technology, thereby promoting the optimal allocation of resources all over the world. It has also changed the original methods of production, consumption, and management, producing new market opportunities [1]. Realizing globalization requires the organization and governance of the global value chain. However, under the background of the global value chain, China's manufacturing industry is always embedded in the global value chain in a low-end manner. Akin to the famous "smile curve", our manufacturing industry is at the low-end of the global value chain. Because its independent innovation capacity is very weak, our country has a subordinate position and is dominated in the global value chain [2]. If we want to change this situation, we need to participate in the international division of labor through the global value chain to improve the country's independent innovation capacity and expand its green 
market. We also need to move toward a high value-added area in the global value chain through green innovation activities to stabilize the position of China's manufacturing industry in the global value chain, thereby enhancing China's competitiveness in the international market.

Since the founding of new China 70 years ago, the manufacturing industry has been at the forefront of China's economic and social development. This industry is an important source of technological innovation and provides a material guarantee of living standards. With the continuous expansion of the scale of the manufacturing industry, this industry is poised to become a "Chinese miracle" in the history of the country's economic development. As the pillar industry of the national economy, China's manufacturing industry is facing increasingly prominent environmental problems. China's manufacturing industry is likely to continue on its development track of high consumption and high pollution [3]. The "13th Five-Year Plan" notes that the full implementation of green manufacturing is one of the most important strategic tasks in China and is the only way to become a strong manufacturing country. "Made in China 2025" emphasizes that green development is an important guideline in the process of the manufacturing industry's transformation [4]. The green technology development of the manufacturing industry must rely on green innovation. "Green" and "innovation" can improve the ability of independent innovation and expand the green market, which is the power source of the transformation in sustainable development from "made in China" to "created in China [5]". Green innovation of the manufacturing industry refers to the inclusion of green technology, products, processes, organization, management, and systems in the manufacturing industry [6]. Moreover, although green innovation can create economic, social, and ecological value, it is also a high-risk activity [7]. The implementation of green innovation in the manufacturing industry entails several high-level uncertain risks. If the innovation activity fails to achieve its expected goals, huge losses may occur. At present, uncertain risk factors are the biggest obstacle to the improvement of green innovation in the manufacturing industry, so risk management is important [8]. To create better economic, social, and ecological value, we need to manage the risk of green innovation scientifically, objectively, and effectively. The identification of green innovation risk cannot determine whether different risk factors affect green innovation activities or the impact degree [9]. Therefore, accurately identifying the risks of the manufacturing industry in the process of value promotion in the global value chain through green innovation is key to the success of green innovation in the manufacturing industry [10].

Unlike the existing research perspectives of domestic and foreign scholars on manufacturing green innovation risk, this paper studies the risk of manufacturing green innovation based on global value chain theory and manufacturing green innovation risk theory. Combined with the characteristics and actual situation of China's manufacturing green innovation, grounded theory is introduced into manufacturing green theory under the global value chain. In the process of qualitative analysis of the innovation risk, in-depth interviews were conducted to investigate the risk of green innovation in the manufacturing industry under the global value chain, and an influencing factor model of green innovation risk in the manufacturing industry of China, rooted in the global value chain, was obtained. Compared with the general qualitative descriptions and analyses of green innovation risk in the manufacturing industry, this study uses more standardized research logic and reasonable research steps and combines the research situations while enhancing the rigor and persuasiveness of the relevant theory. To a certain extent, this study enriches the theoretical research on green innovation risk of the manufacturing industry under the global value chain for the manufacturing industry, while decision making and risk prevention provide the references. Secondly, this paper studies the risk of green innovation in the manufacturing industry from the perspective of the global value chain. It improves the research framework of green innovation risk in the manufacturing industry under the global value chain and comprehensively investigates the impact of green R\&D risk, green manufacturing risk, green marketing risk, and green service risk on manufacturing under the global value chain. This study thus breaks through the limitations of previous one-sided micro research on the impact of green innovation in industry, deeply analyzes the causal relationship between the risks, and constructs a risk 
relationship model of green innovation in the manufacturing industry under the global value chain, thus providing a supplement for research on green innovation risk in the manufacturing industry under the global value chain.

The research contents of this paper are as follows: the second part reviews the documents related to green innovation risk management. The third part designs the identification method of green innovation risk factors. The fourth part provides the identification process of green innovation risk factors. The fifth part outlines the results and models risk identification. The sixth part discusses the conclusions and research direction for the future.

\section{Literature Review}

\subsection{Green Innovation Risk}

Green innovation was first proposed by E. Brawn and D. Wield (1994) [11]. Green innovation has different appellations according to different disciplines of scholars and different purposes of researchers. Therefore, green innovation is often called ecological innovation, environmental innovation, environment driven innovation and sustainable innovation [12]. However, in the process of green innovation, due to the uncertainty of external environment, the difficulty and complexity of green innovation activities, and the limitation of innovators' own ability and strength, green innovation activities cannot achieve the expected goal. It can be seen that green innovation has uncertain risks, as scholars all over the world have different views on the concept of green innovation risk. Abernathy, an American scholar, believed that the innovation risk can be avoided because the risk is caused by a lack of information [13]. Otway, a risk expert, regarded risk as a disaster and argues that risk relates to technology [14]. George (2002) and others maintain that the risks of enterprise technological innovation include seven factors: R\&D risk, production risk, financial risk, market risk, policy risk, cultural risk, and management risk [15-17]. Linquiti Peter (2012) and Scott F. Latham (2009) believed that technological innovation risk cannot be ignored; in the evaluation process of R\&D projects, it must be listed in the R\&D project evaluation system as an important factor [18]. Miorando (2014) summarized 12 risk types and 43 risk factors in the process of technological innovation by reviewing the existing literature [19]. Chinese scholars also have different ideas on the concept of green innovation risk. Zhao argued that innovation risk can cause corresponding losses when the risk information is not clear, while Gong maintained that the uncertainty of risk is the fault of human judgment because people are uncertain about development trends [20]. Chen and Xu (2017) argued that innovation and risk are important issues in development [21]. Therefore, scholars at home and abroad have analyzed green innovation risk from both a subjective and objective perspective. Green innovation risk is inherently uncertain. People cannot accurately determine risk development at a subjective level, so the risk at an objective level is even more unpredictable.

\subsection{Related Factors of Green Innovation}

In recent years, many scholars have studied the factors of green innovation. Most scholars believe that green innovation is largely influenced by government regulations, market pulling forces, and technological promotion. Yang and Bi (2018) constructed a transmission mechanism of green innovation power among industrial enterprises in the open economy from three perspectives: the technological driving force, the market driving force, and the environmental regulation driving force [22]. Horbach (2012) summarized the driving factors of green innovation into four aspects: technological promotion, market pushing, regulation incentives, and internal factors of enterprises [23]. Saunila et al. (2018) maintained that green innovation is driven by economic and institutional pressure and can create value in social sustainability. El-Kassar and Singh (2018) developed and tested an overall model for the relationship between green innovation and its driving factors, as well as the factors that help overcome technological challenges, affect enterprise performance, and offer competitive advantage [24]. Fernando et al. (2019) extended the concept of green business by studying an original 
conceptual framework, proposing that service innovation capability mediates the relationship between sustainable organizational performance and environmental innovation [25].

\subsection{Risk Identification of Green Innovation}

In the basic process of risk management, the first step of risk management is risk identification (Zhou and Xue, 2002). Qualitative analysis is a common method for risk identification ( $\mathrm{Wu}, 2000)$. Generally, literature analysis, the flow chart method, fault tree analysis, and risk lists are used in risk identification. Trott (2006) summarized the relevant risks [26]. Baryannis et al. (2019) identified the risks in each link of the system through a flow chart and emphasized the correlation between risk factors [27]. $\mathrm{Ma}$ and Li (2016) identified the risks of the Harbin-Mudanjiang railway project [28]. Liu et al. (2016) described the logical relationship between different levels of risk in low-carbon breakthrough innovation under the global value chain through a risk list based on the Hall Three-dimensional model [29].

Above all, existing studies mainly focus on empirical analysis, producing in-depth analyses on the most prominent risks. Scholars have paid the most attention to the influencing factors of risk, risk management, and other aspects. The models and conclusions obtained are not very stable and cannot systematically reflect the overall situation of green innovation risk. At present, the theoretical research foundation of green innovation risk for the manufacturing industry under the global value chain is insufficiently mature. If one takes China's provincial panel data as the research object, there are some limitations. In view of this problem, the present paper introduces the qualitative research method of grounded theory to identify the risk of green innovation in the manufacturing industry based on the background of the global value chain to compensate for the deficiency of the relevant research.

\section{Research Method and the Design of Risk Factor Identification}

\subsection{Research Methods}

In the 1960s, the American sociologists Glaser and Strauss proposed grounded theory. Grounded theory refers to a research method used to explore and summarize the causes of a certain phenomenon by collecting and analyzing data in a standardized and systematic way. This theory provides a type of bottom-up method to standardize the relevant qualitative research. Usually, researchers do not set any theoretical hypotheses before the research starts, as this model is only based on the original interview data and relevant practical experience. Although it is supported by certain empirical evidence and does not take empirical research as its theoretical framework, this model abstracts new concepts from empirical facts, thereby forming new ideas. Unlike other qualitative research methods, grounded theory pays more attention to the integrity and practicality of theoretical construction [30]. After many years of development, grounded theory has been gradually applied to management, education, religion, and many other areas [31-34]. The research flow of grounded theory is shown in Figure 1. Grounded theory is a breakthrough in qualitative research methods that perfectly solves the problems that other qualitative research methods cannot. The standardization and normalization of grounded theory compensate for the problems and deficiencies in other qualitative research methods. The research results of green innovation risk in the manufacturing industry under the global value chain are lacking theoretical support. At the same time, in past studies, most of the research on green innovation risk in the manufacturing industry under the global value chain adopted the quantitative research method of using a large sample questionnaire survey to test a theoretical hypothesis. Instead, this paper uses the qualitative research method of grounded theory to identify the green innovation risk of the manufacturing industry under the global value chain, as this method has good applicability for the research situation of the present study. 


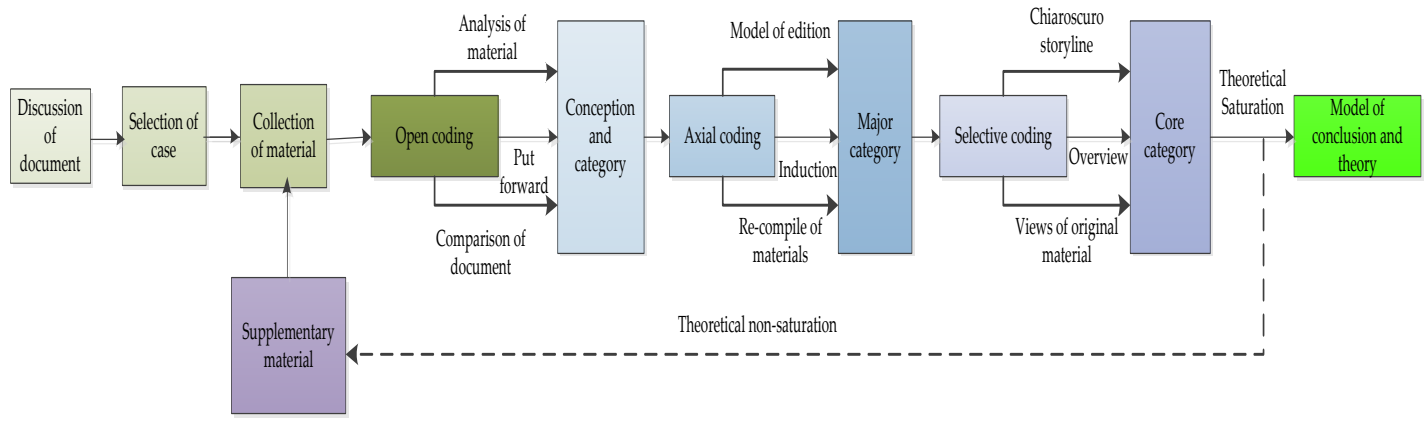

Figure 1. The research flow of grounded theory.

\subsection{Selection of the Research Objects}

To closely fit the research background of this paper and realize the effective identification of green innovation risk in the manufacturing industry under the global value chain, the interviewees in this paper are all from medium-sized and larger enterprises. They are thus well-educated middle-level managers of high-quality enterprises. Fassinger and other scholars note that in the study of grounded theory, the appropriate number of survey samples is 20-30. According to the categorical determination of the sample number in the coding process, it is appropriate to select the frequency of concept words that appear more than 2-3 times in the data [35]. Under the principle of strictly ensuring theoretical saturation, this paper selects 25 manufacturing enterprises as its samples. The sample enterprises are all large and medium-sized manufacturing enterprises. These enterprises belong to the general equipment manufacturing industry; special equipment manufacturing industry; transportation equipment manufacturing industry; the computer, communication, and other electronic equipment manufacturing industries. The composition of the interviewees is shown in Figure 2.

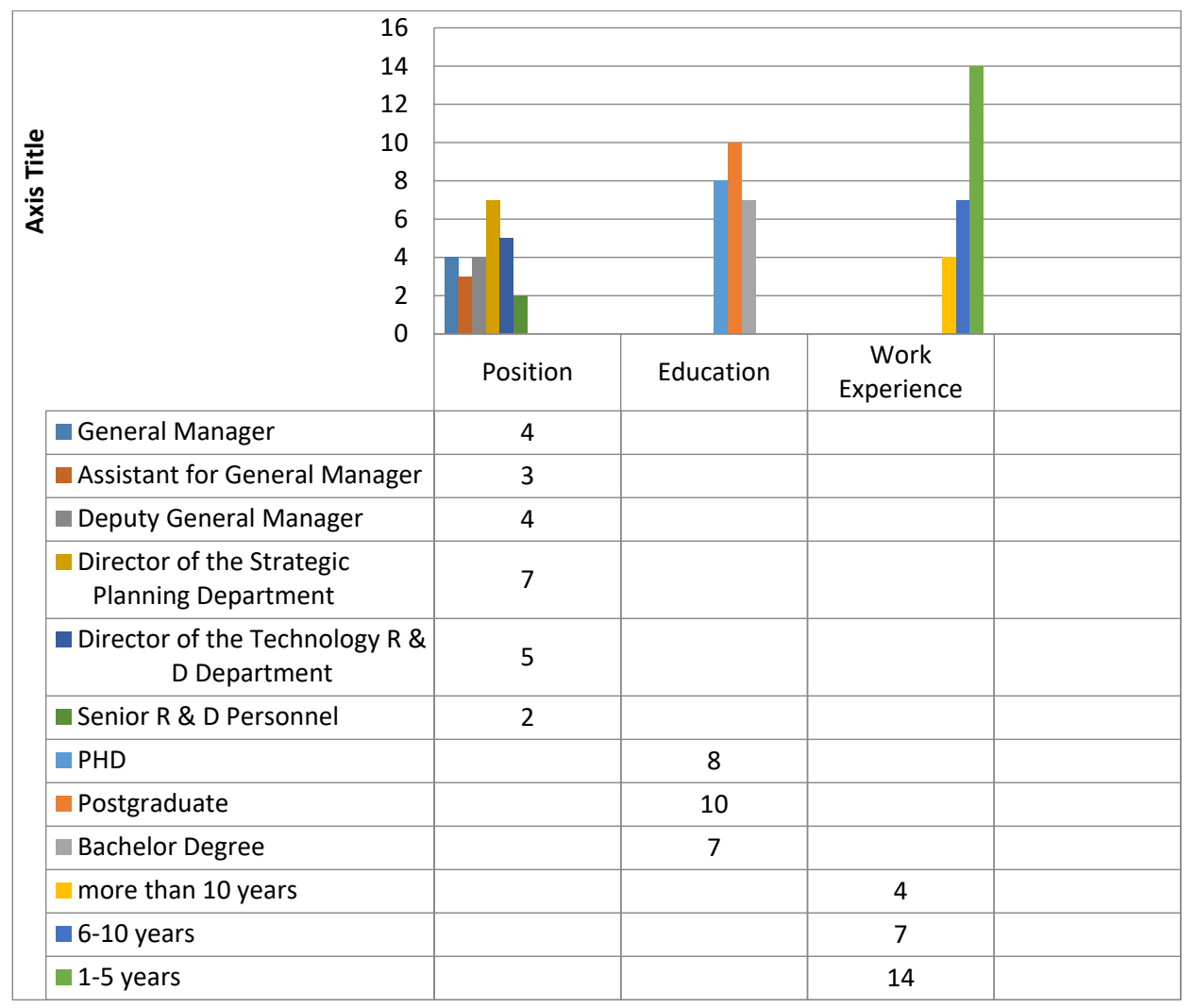

Figure 2. The composition of the interviewees. 


\subsection{Data Sources and Collections}

In this study, 25 interviewees were interviewed one-on-one to investigate and analyze the risk factors of green innovation in the manufacturing industry. The interview time of each interviewee was controlled for more than one hour, and during the interview, we focused on the adjustment of atmosphere and rhythm to accurately understand the opinions and views of the interviewees on the risk factors of green innovation. The content of each interview mainly focused on measures to improve green innovation and the factors affecting the implementation effect of green innovation, such as "What is the main motivation and the purpose of green innovation in your company?", "Under what circumstances will your company carry out green innovation?", "What resources and capabilities does your company have to implement green innovation?", and "What factors can promote low carbon and conservation in the management and operations of your company?" [36]. Through in-depth interviews, we obtained 25 enterprise interview records. Due to the large industry span of the sample enterprises, we checked the interview records to ensure that the chosen interviewees reflected the authenticity of green innovation in the manufacturing industry. We randomly selected 20 enterprise interview records as the original coding analysis materials for the research on identifying the influencing factors of green innovation risk in the manufacturing industry of the global value chain using grounded theory. The remaining five interview records were used as the theoretical saturation test materials for the identification results of grounded theory and as the basis for re-verification of the identification and aggregation results [27]. Finally, we analyzed the data through open coding, axial coding, and selective coding. To ensure the reliability and validity, we strictly followed the steps of categorical induction and model construction in the process of coding. We then conceptualized and categorized the interview materials and modified and deleted controversial concepts and categories on the basis of the experts' opinions to avoid the influence of the coders' subjectivity and improve the objectivity of the coding [37].

\section{Identification Process of the Green Innovation Risk Factors}

\subsection{Open Coding}

Open coding is a data integration process in which all the original interview materials are scattered, and then the original interview content is analyzed, extracted, coded, labeled, and logged in line by sentence to determine the concept categories and realize the conceptualization and categorization of the interview content. After the interview, we sorted more than 1000 original sentences and corresponding initial concepts. After sorting and analyzing this content several times, we eliminated the initial concepts that appeared fewer than three times. Finally, we abstracted 31 concept categories from the data. Considering the limited space of this article, we only selected some categories and initial concepts through open coding, as shown in Appendix A.

\subsection{Axial Coding}

According to the axial coding steps, we obtained more strict main categories based on open coding. Throughout the analysis, we found some potential logical relations among the 31 independent categories obtained by open coding. According to the internal relations between the different categories, we reclassified them, thereby obtaining four main categories. Table 1 shows the corresponding axial coding categories of each main category.

\subsection{Selective Coding}

According to the steps of selective coding, we used axial coding to determine the main categories. By analyzing the relationship between each main category, we found the causal relationship between the core category and the main category and then described the phenomenon and context structure as a "storyline". This logical storyline formed the bases of the "grounded" theory. 
Table 1. The results of the axial coding.

\begin{tabular}{|c|c|c|}
\hline Main Categories & Corresponding Categories & The Connotations of Categories \\
\hline \multirow{7}{*}{$\begin{array}{l}\text { Green R\&D risk under the } \\
\text { global value chain }\end{array}$} & $\begin{array}{c}\text { Proportion of global green R\&D } \\
\text { personnel investments }\end{array}$ & $\begin{array}{l}\text { In the process of global green } R \& D \text {, } \\
\text { the proportion of relevant R\&D } \\
\text { personnel to the total number of } \\
\text { employees in the world. }\end{array}$ \\
\hline & $\begin{array}{c}\text { Proportion of global green } \mathrm{R} \& \mathrm{D} \\
\text { investments }\end{array}$ & $\begin{array}{l}\text { In the process of global green } R \& D \text {, } \\
\text { the proportion of } R \& D \text { investment in } \\
\text { operating revenue. }\end{array}$ \\
\hline & Stability of global green R\&D & $\begin{array}{l}\text { In the global green R\&D process of the } \\
\text { manufacturing industry, due to the } \\
\text { complex, advanced, and mature } \\
\text { characteristics of green technology, } \\
\text { green technology and its changes } \\
\text { are uncertain. }\end{array}$ \\
\hline & $\begin{array}{l}\text { Life cycle uncertainty of global } \\
\text { green R\&D }\end{array}$ & $\begin{array}{l}\text { In addition to personnel and capital } \\
\text { investment, R\&D also needs time to } \\
\text { invest. Due to the high complexity of } \\
\text { green } R \& D \text {, the length of time for new } \\
\text { green technology to replace the green } \\
\text { technology under development } \\
\text { is uncertain. }\end{array}$ \\
\hline & $\begin{array}{l}\text { Stability of global green } \\
\text { technology applications }\end{array}$ & $\begin{array}{l}\text { The possibility that the low-orbit } \\
\text { green technology being developed } \\
\text { will be replaced by other, more } \\
\text { advanced, high-orbit } \\
\text { green technology. }\end{array}$ \\
\hline & $\begin{array}{l}\text { The difficulty of the international } \\
\text { transfer of green technology }\end{array}$ & $\begin{array}{l}\text { Green innovation technology can be } \\
\text { transferred from one party to another. } \\
\text { The success or failure of green } \\
\text { technology diffusion and the } \\
\text { achievement of transformation in } \\
\text { different regions is mainly limited by } \\
\text { the supply capacity of the technology } \\
\text { providers. Another reason is the } \\
\text { maturity of the technology itself. }\end{array}$ \\
\hline & $\begin{array}{l}\text { International protection of green } \\
\text { technology patents }\end{array}$ & $\begin{array}{l}\text { To limit the abuse of intellectual } \\
\text { property rights, relatively uniform } \\
\text { international laws will be produced } \\
\text { through the coordination of } \\
\text { international intergovernmental } \\
\text { organizations in accordance with the } \\
\text { relevant provisions of various } \\
\text { countries' intellectual property rights } \\
\text { to protect green technology patents. }\end{array}$ \\
\hline
\end{tabular}


Table 1. Cont.




Table 1. Cont.

\begin{tabular}{|c|c|c|}
\hline Main Categories & Corresponding Categories & The Connotations of Categories \\
\hline \multirow{9}{*}{$\begin{array}{l}\text { Green marketing risks } \\
\text { under the global } \\
\text { value chain }\end{array}$} & $\begin{array}{l}\text { Proportion of global green } \\
\text { marketing staff investments }\end{array}$ & $\begin{array}{l}\text { In the global green marketing process } \\
\text { of the manufacturing industry, } \\
\text { the number of marketing staff } \\
\text { accounts for the proportion of the total } \\
\text { number of employees in } \\
\text { the enterprise. }\end{array}$ \\
\hline & $\begin{array}{l}\text { Proportion of global green } \\
\text { marketing investments }\end{array}$ & $\begin{array}{l}\text { In the process of global green } \\
\text { marketing of the manufacturing } \\
\text { industry, the proportion of marketing } \\
\text { funds in operating revenue. }\end{array}$ \\
\hline & $\begin{array}{l}\text { International demand level of } \\
\text { green products }\end{array}$ & $\begin{array}{l}\text { In the international market, the total } \\
\text { amount of green products in the } \\
\text { manufacturing industry for which } \\
\text { consumers have purchase intentions } \\
\text { that can be realized. }\end{array}$ \\
\hline & $\begin{array}{l}\text { International market recognition } \\
\text { of green products }\end{array}$ & $\begin{array}{l}\text { In the international market, } \\
\text { consumers' affection for and } \\
\text { satisfaction with the green products in } \\
\text { the manufacturing industry. }\end{array}$ \\
\hline & $\begin{array}{l}\text { International market share of } \\
\text { green products }\end{array}$ & $\begin{array}{l}\text { The proportion of manufacturing } \\
\text { green products in the international } \\
\text { market sales of similar products. }\end{array}$ \\
\hline & $\begin{array}{c}\text { Competition intensity of green } \\
\text { products in the } \\
\text { international market }\end{array}$ & $\begin{array}{l}\text { The total quantity, ability, and unfair } \\
\text { competition of competitors producing } \\
\text { green innovative products on the } \\
\text { global market. }\end{array}$ \\
\hline & $\begin{array}{l}\text { Green products' share of existing } \\
\text { international marketing channels }\end{array}$ & $\begin{array}{c}\text { The utilization of existing marketing } \\
\text { outlets in the sales process of green } \\
\text { products in the } \\
\text { manufacturing industry. }\end{array}$ \\
\hline & $\begin{array}{l}\text { Commercialization and } \\
\text { internationalization of green } \\
\text { technology }\end{array}$ & $\begin{array}{l}\text { The enterprise transforms green } R \& D \\
\text { achievements into green products and } \\
\text { makes full use of various resources at } \\
\text { home and abroad in cross-border } \\
\text { economic cooperation. }\end{array}$ \\
\hline & $\begin{array}{l}\text { The intensity of green technical } \\
\text { barriers to trade in the } \\
\text { international community }\end{array}$ & $\begin{array}{l}\text { The extent to which trade protection } \\
\text { in the international community } \\
\text { hinders the sale of green products on } \\
\text { the international market. }\end{array}$ \\
\hline
\end{tabular}


Table 1. Cont.

\begin{tabular}{|c|c|c|}
\hline Main Categories & Corresponding Categories & The Connotations of Categories \\
\hline \multirow{5}{*}{$\begin{array}{l}\text { Green services under the } \\
\text { global value chain }\end{array}$} & $\begin{array}{l}\text { Proportion of global green service } \\
\text { staff investments in the } \\
\text { manufacturing industry }\end{array}$ & $\begin{array}{l}\text { When enterprises provide green } \\
\text { services on the international market, } \\
\text { the number of their service staff } \\
\text { accounts for the proportion of the total } \\
\text { number of employees. }\end{array}$ \\
\hline & $\begin{array}{l}\text { Proportion of global green service } \\
\text { investments in the } \\
\text { manufacturing industry }\end{array}$ & $\begin{array}{l}\text { When enterprises provide green } \\
\text { services on the international market, } \\
\text { the amount of service funds accounts } \\
\text { for the proportion of business income. }\end{array}$ \\
\hline & $\begin{array}{c}\text { Coverage of global green service } \\
\text { outlets in the } \\
\text { manufacturing industry }\end{array}$ & $\begin{array}{c}\text { The proportion of the number of } \\
\text { outlets provides green services based } \\
\text { on the total number in all } \\
\text { market areas. }\end{array}$ \\
\hline & $\begin{array}{l}\text { Global level of the green product } \\
\text { supply chain in the } \\
\text { manufacturing industry }\end{array}$ & $\begin{array}{l}\text { The degree of the cross circulation of } \\
\text { business flow, logistics, information } \\
\text { flow, and capital flow from a global } \\
\text { perspective in the process of } \\
\text { enterprises purchasing raw materials } \\
\text { and parts of green products } \\
\text { (manufacturing intermediates, to } \\
\text { products, to final products) and } \\
\text { delivering green products to } \\
\text { consumers through sales channels. }\end{array}$ \\
\hline & $\begin{array}{l}\text { Global after-sale technical service } \\
\text { ability of green products in the } \\
\text { manufacturing industry }\end{array}$ & $\begin{array}{l}\text { The service quality and efficiency of } \\
\text { the installation configuration, } \\
\text { use guidance, and fault handling. } \\
\text { The service quality and efficiency of } \\
\text { information inquiry, customer } \\
\text { information acquisition, consultation, } \\
\text { and technical training provided by } \\
\text { the enterprises. }\end{array}$ \\
\hline
\end{tabular}

Table 2 shows the typical relational structure of the main categories in this paper. Through an in-depth investigation and analysis of the four main categories, we identified the core category of "green innovation risk in the manufacturing industry". In the storyline of "green innovation risk in the manufacturing industry", green R\&D risk under the global value chain, green manufacturing risk under the global value chain, green marketing risk under the global value chain, and green service risk under the global value chain have significant impacts on the green innovation of the manufacturing industry.

\subsection{Theoretical Saturation Test}

In this paper, the interview data of the remaining five enterprises were coded repeatedly to verify the typical relational structure of "Green innovation risk in the manufacturing industry under the global value chain".

Take H company as an example. During the "13th Five-Year Plan" period, as the leader of energy conservation and related functions in the industry, $\mathrm{H}$ company used the "smart energy conservation ecosystem" as its development strategic plan. It carried out green innovation activities and provided its consumers with world-leading green products. $\mathrm{H}$ company established a comprehensive scientific research base through alliances with enterprises from the United States, Japan, Germany, and other countries to realize the iterative replacement of its core technologies. By the end of 2017, the sales volume of $\mathrm{H}$ company in the washing machine industry ranked first in several countries for several 
consecutive years, and its invention patents also ranked first for several consecutive years. In 2018, $\mathrm{H}$ company was selected as one of the most innovative enterprises in the world for the third time and was the only selected brand among domestic appliance enterprises. In the "The second batch of green manufacturing system construction demonstration list in 2017", published on the website of the Ministry of Industry and Information Technology, H company accounted for 16 of the 26 refrigerators shortlisted and was the brand with the largest number of publicized products in the industry. At the same time, $\mathrm{H}$ company was included in the list of "green supply chain management demonstration enterprises", so it had obvious advantages in green manufacturing technology. In 2020, in the list of the top 100 most valuable global brands of Brand Z, 17 Chinese brands were included. H company was once again listed as the world's only Internet of things ecological brand. Its brand value significantly improved, and its global ranking increased from 89th to 68th. In terms of service, it adhered to the concept of "everything for users" for the products and services it provided to users. It also ensured the quality of its product's services. To accurately meet the needs of its users, the company applied its own technology and global integrated technical resources to carry out product innovation. In this way, the company discovered potential customer service value propositions, making mass customization possible. H company not only has a competitive advantage in R\&D but is also a first-class after-sale service. It is impossible for other companies to imitate this company's after-sale service teams or the construction of an after-sale system in a short period of time.

Table 2. The results of the selective coding.

\begin{tabular}{|c|c|}
\hline Typical Relational Structure & Connotations of the Relational Structure \\
\hline $\begin{array}{l}\text { Green } R \& D \text { risk under the global value chain } \\
\qquad \rightarrow \text { Green Innovation }\end{array}$ & $\begin{array}{l}\text { The proportion of R\&D personnel investments, R\&D capital } \\
\text { investments, the stability of R\&D, uncertainty of the R\&D } \\
\text { life-cycle, the difficulty of the international transfer of } \\
\text { technology, and international protection of the technology } \\
\text { patents have an important impact on the green innovation of } \\
\text { the manufacturing industry. }\end{array}$ \\
\hline $\begin{array}{l}\text { Green manufacturing risk under the global } \\
\text { value chain } \rightarrow \text { Green Innovation }\end{array}$ & $\begin{array}{l}\text { The proportion of manufacturing personnel investment, } \\
\text { the proportion of manufacturing capital investment, } \\
\text { the production scale, the degree of technical performance } \\
\text { requirements of raw materials, the quality and performance } \\
\text { level of manufactured products, the scale of global } \\
\text { outsourcing, the scale of OEM, the degree of technological } \\
\text { transformation, existing international production systems, } \\
\text { the compatibility of green innovation, and the increase rate of } \\
\text { costs play an important role in the green innovation of the } \\
\text { manufacturing industry. }\end{array}$ \\
\hline $\begin{array}{l}\text { Green marketing risk under the global value } \\
\text { chain } \rightarrow \text { Green Innovation }\end{array}$ & $\begin{array}{l}\text { The proportion of marketing staff investment, the proportion } \\
\text { of marketing capital investment, the level of international } \\
\text { demand, the recognition degree of green products on the } \\
\text { international market, the international market share, } \\
\text { the competitive intensity of the international market, } \\
\text { the share of green products in the existing international } \\
\text { marketing channels, the level of technological } \\
\text { commercialization and internationalization, and the intensity } \\
\text { of technical trade barriers within international society play } \\
\text { an important role in the green innovation of the } \\
\text { manufacturing industry. }\end{array}$ \\
\hline $\begin{array}{l}\text { Green service risk under the global value } \\
\text { chain } \rightarrow \text { Green Innovation }\end{array}$ & $\begin{array}{l}\text { The proportion of service staff investment, the proportion of } \\
\text { service capital investment, the coverage of the service outlets, } \\
\text { product supply chain globalization, and global after-sale } \\
\text { technical service capacity play an important role in the green } \\
\text { innovation of the manufacturing industry. }\end{array}$ \\
\hline
\end{tabular}

Above all, the interview materials of $\mathrm{H}$ company are in line with the storyline of the core category of green innovation risk of the manufacturing industry under the global value chain, including green 
$R \& D$ risk under the global value chain, green manufacturing risk under the global value chain, green marketing risk under the global value chain, and green service risk under the global value chain. Next, we again coded and tested the interview data of the remaining four enterprises. The coding results showed that no new category was introduced in the process and also confirmed the core category "the risk of green innovation under the global value chain". This indicated that the category code and the storyline had good theoretical saturation, so sampling could be stopped.

\section{Risk Identification Results and Model Interpretation}

Through the open coding, axial coding, selective coding, and theoretical saturation tests on the interview data, we constructed the risk relationship model of green innovation in the manufacturing industry under the global value chain, as shown in Figure 3.



Figure 3. Risk relationship model of green innovation in the manufacturing industry under the global value chain.

\subsection{Green RED Risk under the Global Value Chain}

Global green innovation R\&D risk refers to the risks that may occur in the R\&D stage of green innovation [38] and mainly includes seven factors: the stability of global green research and development, the uncertainty of the global green research and development life cycle, the proportion of global green R\&D capital investment, the difficulty of the international transfer of green technology in the manufacturing industry, the proportion of global green R\&D personnel investment, and the international protection of manufacturing green technology patents [39]. As a highly professional activity, the research and development of green innovation requires relevant personnel with rich knowledge and experience, as well as sufficient $R \& D$ funds to ensure the innovation process. If $R \& D$ personnel and capital investments are insufficient, the success rate of green innovation will be affected. On the other hand, the risk of R\&D comes from the immaturity of green innovation technology [40]. When enterprises transfer their technology, the uncertainty of the international transfer of green innovation will have negative effects on green innovation. The effectiveness of the international protection of intellectual property is also a key factor [41]. Once the innovation cannot be effectively protected, it will be easily imitated by competitors, which will threaten the benefits of the innovation and increase the risk of green innovation. 


\subsection{Green Manufacturing Risk under the Global Value Chain}

Global green innovation manufacturing risk mainly refers to a failure of innovation due to the uncertainty of relevant factors and their changes in the manufacturing process [42]. The risk of green manufacturing under the global value chain includes 10 factors: the proportion of manufacturing personnel investment, the proportion of manufacturing capital investment, the production scale, the degree of technical performance requirements of raw materials, the quality and performance level of manufactured products, the scale of global outsourcing, the scale of original equipment manufactuce (OEM), the degree of technological transformation, the existing international production system and the compatibility of green innovation, and the increase in cost. To ensure the mass production of green products, sufficient manufacturing personnel and funds are essential [43]. In the process of green innovation, the manufacturing industry puts forward new requirements for the process, equipment, and raw materials. Global outsourcing is a better way to solve the problems of insufficient production conditions and low added value in manufacturing. At this time, changes in the global outsourcing scale also carry risks. Moreover, the scale of OEM will lead to competition for orders among the agents in the international market]. At the same time, the production constraints of the government or international organizations will increase the cost of the production process.

\subsection{Green Marketing Risks under the Global Value Chain}

Green marketing risks under the global value chain include nine factors: the proportion of global green marketing staff investment, the international market competition intensity of green products, the proportion of global green marketing capital investment, the recognition degree of green products on the international market, the international market share of green products, the share of green products in the existing international marketing channels, the international demand level of green products, the level of globalization and internationalization of green technology, and the intensity of green technical barriers to trade in the international community. In the global green innovation marketing stage, if there is no sufficient guarantee of marketing staff and funds, the risk of all marketing activities will be increased. The uncertainty of the international market also has a great impact at this stage. If the demand for green products in the manufacturing industry changes in the international market, the recognition degree of such products will not be high, and the international market share of green products in the manufacturing industry will become too small; moreover, because international market competition is fierce, it will become difficult to use existing international marketing channels. Therefore, it is important for the success of new product marketing to occupy many existing marketing channels [44]. In addition, the commercialization, industrialization, and internationalization of green innovation in the manufacturing industry; the degree of globalization of the green supply chain in the manufacturing industry; the green technical trade barriers in developed countries will also affect the implementation of green marketing activities [45,46].

\subsection{Green Service Risks under the Global Value Chain}

The risks of green services under the global value chain include five factors: the proportion of global green service staff investment, the proportion of global green service capital investment, the coverage rate of global green service outlets, the globalization level of the global green product supply chain, and the global after-sale technical service ability of green products. Human capital and capital investments are the core resources of the service activities in manufacturing enterprises and directly affect the efficiency and effectiveness of innovative product services [47]. The coverage of service outlets is an important factor to check and balance the service ability of the manufacturing industry. The establishment of a perfect service network can improve service efficiency, reduce service costs, and assist the successful promotion of product innovation activities. At the same time, the implementation of "green supply chain management" by large multinational enterprises will also hinder the development of Chinese enterprises and become a new threshold. After-sale technical 
services, also known as after-sale technical support, are used for installation and configuration, providing operational instructions, and handling faults in sold products (processes and services), as well as handling information inquiries, customer information acquisition, consultation, and technical training [48,49]. This type of service helps achieve high customer satisfaction and plays a significant role in promoting the market share of products (processes and services).

\section{Conclusions}

Under the background of the global value chain, the implementation of green innovation is not only the goal but also the means. The implementation of green innovation is an independent and self-reliant road suitable for the development of China. It is also the key to realizing the transformation of China's manufacturing industry from "high consumption, high pollution, and low output" to "low consumption, high output, and low pollution". On the other hand, China's manufacturing industry lacks core technology. In the division of labor of the global value chain, China's characteristics of abundant labor and rich resources remain locked in the low-end link. To ameliorate this situation, it is necessary to realize green innovation in the manufacturing industry to complete the country's ascension in the global value chain. However, green innovation is highly uncertain and risky. By identifying the risks in the process of green innovation, we can reduce these risks, promote the green transformation of the manufacturing industry, and provide a theoretical basis and practical guidance for enterprise managers and policy makers.

Green innovation is an important problem that the manufacturing industry will face. According to the process of grounded theory based on the systematic collection and the analysis of original data, and through the process of open coding, axial coding, and selective coding, this study identified the risks of green innovation in the manufacturing industry against the background of the global value chain: (1) Green innovation risk under the global value chain includes seven factors: the stability of global green research and development, the uncertainty of the global green research and development life cycle, the proportion of global green innovation investment, the difficulty of the international transmission of the manufacturing industry's green technology, the proportion of global green researchers' input, stability of technology, and international protection of the manufacturing industry's green technology patents. (2) Green manufacturing risks under the global value chain include ten factors: the staff proportion of manufacturing, the proportion of capital investments in manufacturing, the production scale, the requirements of the raw materials' technical performance, the quality and performance of the products, the scale of global outsourcing, the scale of OEM, technological transformation, the compatibility of the existing international manufacturing system and green innovation, and increases in cost. (3) Green marketing risks under the global value chain include nine factors: the proportion of global green marketing staff input, the international market competition intensity of green products, the proportion of global green marketing's capital investment, the recognition of green products in the international market, the international market's share of green products, the share of green products in existing international marketing channels, the international demand level of green products, the level of globalization and internationalization, and the intensity of green technical trade barriers in international society. (4) The risk of green services under the global value chain includes five factors: the proportion of global green service staff input, the proportion of global green service capital investment, the fraction of the coverage of the global green service network, the globalization level of the global green product supply chain, and the global after-sales technical service ability for green products.

This study's innovative research into the green innovation risk identification of China's manufacturing industry under the global value chain obtained valuable results. The results of this study will help deepen our comprehensive understanding of green innovation risk and provide a reference for the development of green innovation activities and risk management in the manufacturing industry. This study also provides a theoretical basis for further research. In the future, we will measure the risks identified in this paper by establishing a risk index system and constructing a risk measurement model. Determining the necessary prevention and control measures of risks according 
to the measurement results will be the key element of related research in the future. However, due to the limited time, theoretical level, and research ability of our research, and at the same time, the selection of samples being restricted by the region, the number of samples being too small, and the representativeness needing to be improved, in future research, we will increase and improve the enterprise area and enterprise scale to obtain more accurate analysis data.

Author Contributions: Y.S. original draft, conceptualization, methodology, data collection and format analysis. L.W. writing, review and editing. S.Y. supervision, validation, writing-review and editing. All authors have read and agreed to the published version of the manuscript.

Funding: This research was funded by [the philosophy and social science planning project of Heilongjiang Province, the security research of equipment manufacturing industry in Heilongiang Province under the background of "China-US trade friction"] grant number [KY10900180036]. This research was funded by [Philosophy and social science planning project of Heilongjiang Province: Research on transformation and upgrading path and policy system of manufacturing industry in Heilongiiang Province under the new situation] grant number [20GYB041]. This research was funded by [Baoding Philosophy and Social Science Planning Project] grant number [2020047]. This work was also funded by the Baoding Philosophy and Social Science Planning Project (2020047).

Conflicts of Interest: The authors declare that they have no competing interests.

\section{Appendix A}

Table A1. Open Coding Categorization.

\begin{tabular}{|c|c|c|}
\hline Number & Category & Original Data (Initial Material) \\
\hline 1 & $\begin{array}{l}\text { Proportion of global green } \\
\text { R\&D personnel investment }\end{array}$ & $\begin{array}{l}\text { A3 The staff of the R\&D Department of the enterprise all } \\
\text { have bachelor's degrees or above. Most of them have } \\
\text { master's degrees, and those with doctoral degrees are } \\
\text { increasing year by year. (Human capital) } \\
\text { A7 Last year, the enterprise recruited } 17 \text { high-end talents } \\
\text { from "double first-class" universities and famous foreign } \\
\text { universities with master's degrees or above, and the } \\
\text { enterprise provided a competitive salary and } \\
\text { development platform for them. } \\
\text { (Acquire innovative talents) } \\
\text { A11 The enterprise pays attention to R\&D investments } \\
\text { and technology reserves. It has an independent R\&D } \\
\text { department and nearly } 300 \text { researchers; about one-third } \\
\text { of them have master's degrees or above, and all have } \\
\text { independent R\&D abilities. (Human capital investment) } \\
\text { A19 The enterprise encourages employees to study } \\
\text { abroad and return with more new knowledge and ideas. } \\
\text { (Encourages employees to improve themselves) }\end{array}$ \\
\hline 2 & $\begin{array}{l}\text { Proportion of global R\&D } \\
\text { investment }\end{array}$ & $\begin{array}{l}\text { A2 The enterprise's annual R\&D investment accounted } \\
\text { for more than } 17 \% \text { of its marketing revenue } \\
\text { (nearly } 20 \% \text { last year). (R\&D investment) } \\
\text { A5 The enterprise obtains part of its financial support } \\
\text { through financial institutions and venture capital } \\
\text { institutions for their own energy conservation and } \\
\text { emission reduction projects to guarantee the material } \\
\text { basis of innovation. (Acquire innovation capital) } \\
\text { A13 Last year, the enterprise invested two-hundred } \\
\text { thousand yuan into the research and development of an } \\
\text { experimental desulfurization device. } \\
\text { (Capital investment) } \\
\text { A21 The implementation of green innovation in the } \\
\text { enterprise is faced with a high-cost risk, and the } \\
\text { uncertainty of income makes it difficult to obtain the } \\
\text { financial support of shareholders, so the R\&D projects } \\
\text { are difficult to carry out. (Capital support) }\end{array}$ \\
\hline
\end{tabular}


Table A1. Cont.

\begin{tabular}{|c|c|c|}
\hline Number & Category & Original Data (Initial Material) \\
\hline 3 & $\begin{array}{l}\text { Stability of global green } \\
\text { research and development }\end{array}$ & $\begin{array}{l}\text { A6 In the past three years, the enterprises have been } \\
\text { increasing their investments in green innovation, } \\
\text { especially in the research and development of } \\
\text { environmental protection projects. (Research and } \\
\text { development of environmental protection products) } \\
\text { A10 Although enterprises have invested much into green } \\
\text { innovation in the current period, the immature level of } \\
\text { its R\&D technology and the workload and difficulty of } \\
\text { the R\&D personnel also affect the success rate of R\&D. } \\
\text { (Investment risk) } \\
\text { A22 Enterprises have a stable long-term cooperative } \\
\text { relationship. They often participate in conferences, } \\
\text { exhibitions, and other exchange activities organized by } \\
\text { industry associations, serving as the main members to } \\
\text { establish stable social relations with other organizations. } \\
\text { (Stable partnership) } \\
\text { A25 The talent hunting of the headhunting company } \\
\text { makes increases the conflicts between the superiors and } \\
\text { the subordinates in the team continuously. The lack of } \\
\text { good communication and coordination ability among the } \\
\text { team members leads to instability of the development } \\
\text { team and causes the team members to leave the product } \\
\text { development team. It has a certain impact on the } \\
\text { enterprise. (Unstable R\&D environment) }\end{array}$ \\
\hline 4 & $\begin{array}{l}\text { Uncertainty of global green } \\
\text { R\&D life cycle }\end{array}$ & $\begin{array}{l}\text { A4 Green innovation of an enterprise is a high-risk and } \\
\text { high-cost activity, requiring great investment of } \\
\text { resources into capital, human, and material resources. } \\
\text { However, due to the complexity of green R\&D, the R\&D } \\
\text { life cycle may be too long, resulting in losses. (R\&D life } \\
\text { cycle is too long) } \\
\text { A17 Enterprises do not artificially maintain a product } \\
\text { without a market. Making money is the ultimate goal of } \\
\text { an enterprise. The key point is to ensure that the } \\
\text { business portfolio is balanced; that is to say, there should } \\
\text { be products at all stages of the product life cycle. } \\
\text { (Product life cycle) } \\
\text { A24 If a product is in trouble early in its life cycle, it must } \\
\text { be decided quickly whether to redevelop the product or } \\
\text { abandon it. Ensure that this step is incorporated into the } \\
\text { product plan to maintain objectivity in subsequent } \\
\text { operations. (Product growth period) }\end{array}$ \\
\hline 5 & $\begin{array}{l}\text { Stability of global green } \\
\text { technology applications }\end{array}$ & $\begin{array}{l}\text { A2 The strategic decision makers of green innovation } \\
\text { activities of enterprises are the managers of the } \\
\text { enterprises. They convene project members from all } \\
\text { departments according to the needs of the green } \\
\text { innovation activities. (Allocation of green innovation } \\
\text { resources) } \\
\text { A15 To be more scientific and provide environmental } \\
\text { protection to deal with pollution, enterprises adopt green } \\
\text { technology for their sewage treatment to classify the } \\
\text { treatment of sewage. Sewage treatment can thus reach } \\
\text { the standard of grade II and III directly. (Mature } \\
\text { technology) } \\
\text { A17 In recent years, a large number of safety accidents } \\
\text { and dangerous problems have had a great influence on } \\
\text { the stability of the whole working environment. } \\
\text { The adoption of corresponding green mining technology } \\
\text { will help China's mining development become more } \\
\text { stable and safer. (Green technology application) }\end{array}$ \\
\hline
\end{tabular}


Table A1. Cont.

\begin{tabular}{|c|c|c|}
\hline Number & Category & Original Data (Initial Material) \\
\hline 6 & $\begin{array}{l}\text { The ease of the international } \\
\text { transfer of green technology }\end{array}$ & $\begin{array}{l}\text { A7 When transferring technology, there will be } \\
\text { uncertainty in the international transfer of green } \\
\text { innovation, which has a negative impact on green } \\
\text { innovation. (Technology transfer risk) } \\
\text { A9 Our company attaches great importance to } \\
\text { international economic and technological cooperation. } \\
\text { To catch up with the advanced level of the world as soon } \\
\text { as possible, we should speed up our own scientific and } \\
\text { technological research through the introduction, } \\
\text { digestion, and absorption of international technology } \\
\text { transfer. (International Economic and technological } \\
\text { cooperation) }\end{array}$ \\
\hline 7 & $\begin{array}{l}\text { International Protection of } \\
\text { green technology patents }\end{array}$ & $\begin{array}{l}\text { A5 The innovation achievements of enterprises will } \\
\text { obtain property rights protection through patent } \\
\text { applications and other means. There is also the leakage } \\
\text { of innovation information. The law of intellectual } \\
\text { property protection in China is not perfect, which may } \\
\text { lead to conflicts. (Intellectual property protection) } \\
\text { A7 Due to the imperfection of technology and law, } \\
\text { someone imitates, manufactures, and sells fake and } \\
\text { poor-quality products to seek huge profits, leading to } \\
\text { technical losses and the leakage trade secrets. In recent } \\
\text { years, the infringement of intellectual property rights has } \\
\text { been repeatedly prohibited in many countries. } \\
\text { (Infringement Act) } \\
\text { A16 The establishment and improvement of an } \\
\text { intellectual property protection system is conducive to } \\
\text { motivating the enthusiasm of R\&D staff. (Policy support) }\end{array}$ \\
\hline 8 & $\begin{array}{l}\text { Proportion of global green } \\
\text { manufacturing } \\
\text { personnel input }\end{array}$ & $\begin{array}{l}\text { A1 Enterprise production personnel are from technical } \\
\text { secondary schools, colleges, or above, and they begin to } \\
\text { practice in this field during their internships in the city of } \\
\text { the production and manufacturing work, leading to } \\
\text { skilled operation. (Human capital) } \\
\text { A5 Enterprises determine their production personnel } \\
\text { quota according to the positions determined in the } \\
\text { design of the production line. For example, the rated } \\
\text { personnel quota of a gravure machine is 3-that is to say, } \\
\text { only } 3 \text { people can do it. (According to the equipment } \\
\text { quota) } \\
\text { A14 Creating a healthy and safe environment is } \\
\text { conducive to the improvement and maintenance of the } \\
\text { physical and mental health of employees; it will be also } \\
\text { conducive to creating a good social environment. } \\
\text { (Working environment) }\end{array}$ \\
\hline 9 & $\begin{array}{l}\text { Proportion of global green } \\
\text { manufacturing investment }\end{array}$ & $\begin{array}{l}\text { A3 The persons in charge and the manufacturing } \\
\text { personnel of the enterprise participate in the } \\
\text { manufacturing-related education and training organized } \\
\text { by qualified training institutions, and internal education } \\
\text { and training are carried out according to the classes, } \\
\text { levels, and nature of the work. (Education and training) } \\
\text { A8 In recent years, enterprises have spent a large amount } \\
\text { of money on on-site pollution control, setting up car } \\
\text { washing tanks, dust control, noise control, disposing of } \\
\text { construction waste into the pool, drainage measures, and } \\
\text { so on. (Capital investment) } \\
\text { A12 The company invested a part of the funds into the } \\
\text { use of safety and environmental protection, the purchase } \\
\text { of safety protection equipment and mechanical } \\
\text { equipment, and accessories for regular inspection. } \\
\text { (Safety and environmental protection funds) }\end{array}$ \\
\hline
\end{tabular}


Table A1. Cont.

\begin{tabular}{|c|c|c|}
\hline Number & Category & Original Data (Initial Material) \\
\hline 10 & $\begin{array}{c}\text { Production scale of } \\
\text { global green } \\
\text { manufacturing products }\end{array}$ & $\begin{array}{l}\text { A4 The company's multi-cylinder diesel engine has } \\
\text { passed three national emission standards, and the annual } \\
\text { production capacity of this diesel engine can reach } \\
1.2 \text { million. (Production capacity) } \\
\text { A6 In the past three years, the company has replaced a } \\
\text { quarter of its old production equipment, adding } \\
100 \text { advanced units of production equipment. (Amount } \\
\text { of production equipment) } \\
\text { A11 We planned a corresponding production plan by } \\
\text { defining the minimum and maximum scale limits of the } \\
\text { product and the load rate of the equipment. } \\
\text { (Production plan) }\end{array}$ \\
\hline 11 & $\begin{array}{l}\text { Requirements of global green } \\
\text { manufacturing for products } \\
\text { based on the technical } \\
\text { performance of raw } \\
\text { materials }\end{array}$ & $\begin{array}{l}\text { A3 Our company should try its best to acquire the same } \\
\text { manufacturer, serial number, and production date for the } \\
\text { raw materials used in the products of the unified } \\
\text { production batch. (Product raw material requirements) } \\
\text { A12 Enterprises use the storage of raw materials, which } \\
\text { require relatively stable temperatures, sunlight and } \\
\text { seasonal changes, and day to night changes will be } \\
\text { considered as well. (Storage standards) }\end{array}$ \\
\hline 12 & $\begin{array}{l}\text { Quality and performance } \\
\text { level of global green } \\
\text { manufacturing products }\end{array}$ & $\begin{array}{l}\text { A1 Starting last year, the company introduced the } \\
\text { world's leading production equipment from abroad and } \\
\text { trained relevant technical personnel. Now this } \\
\text { equipment has been put into use, and the utilization rate } \\
\text { of the newly introduced equipment for raw materials is } \\
\text { greater than } 90 \% \text {, thus changing the production scale of } \\
\text { the enterprise. (Obtain advanced equipment) } \\
\text { A7 The enterprise uses a series parallel production line. } \\
\text { Some production links can be changed at any time as } \\
\text { needed. The main production links are solved by parallel } \\
\text { connection. (Production link) }\end{array}$ \\
\hline 13 & $\begin{array}{l}\text { Global outsourcing scale of } \\
\text { green products }\end{array}$ & $\begin{array}{l}\text { A5 In the process of green innovation, the manufacturing } \\
\text { industry puts forward new requirements for processes, } \\
\text { equipment, and raw materials. Global outsourcing is a } \\
\text { better way to solve the problems of insufficient } \\
\text { production conditions and low added value } \\
\text { manufacturing links of innovation subjects. At this time, } \\
\text { the changes in global outsourcing models will also bring } \\
\text { risks. (Global outsourcing risk) } \\
\text { A8 Because offshore outsourcing is global competition, } \\
\text { although the main players in this competition are } \\
\text { enterprises, the overall competitiveness of the country is } \\
\text { crucial. Due to the relatively low cost, developing } \\
\text { countries have certain advantages in global competition. } \\
\text { (Fierce outsourcing competition) } \\
\text { A10 Service outsourcing is an important way for } \\
\text { countries to participate in the division of economic } \\
\text { globalization in the development of the internet's } \\
\text { information, which is also an important way to enhance } \\
\text { the status of the global value chain. (Service outsourcing) }\end{array}$ \\
\hline
\end{tabular}


Table A1. Cont.

\begin{tabular}{|c|c|c|}
\hline Number & Category & Original Data (Initial Material) \\
\hline 14 & $\begin{array}{l}\text { International OEM scale of } \\
\text { green manufacturing } \\
\text { products }\end{array}$ & $\begin{array}{l}\text { A6 On the other hand, the OEM scale will lead to } \\
\text { competition for orders among agents in the international } \\
\text { market, resulting in fierce competition among } \\
\text { enterprises. (Competing for orders) } \\
\text { A9 China is the world's largest producer and has become } \\
\text { a "world factory", especially in the field of consumer } \\
\text { goods such as clothing, bags, and 3C digital products. } \\
\text { At the same time, the OEM model also supports most of } \\
\text { the world's famous brands. (OEM model) } \\
\text { A13 Large-scale orders can form a relatively stable scale } \\
\text { benefit, but we have to admit that the biggest defect of } \\
\text { the OEM model is that it cannot control its own } \\
\text { development direction. (Disadvantages of OEM) }\end{array}$ \\
\hline 15 & $\begin{array}{l}\text { Global green manufacturing } \\
\text { technology transformation }\end{array}$ & $\begin{array}{l}\text { A2 The enterprise has } 2837 \text { units of advanced production } \\
\text { equipment, more than } 20 \% \text { of which are imported } \\
\text { large-scale pieces of intelligent equipment. (Production } \\
\text { equipment) } \\
\text { A8 Enterprises consider investment in technological } \\
\text { transformation as the breakthrough point that will drive } \\
\text { investment and contribute to stable growth. At the same } \\
\text { time, it will integrate information technology into R\&D, } \\
\text { production, and circulation; promote the integration of } \\
\text { informatization and industrialization; help with } \\
\text { transformation. (Technical transformation) } \\
\text { A22 Enterprises actively recommend major technical } \\
\text { transformation projects that meet the policy and market } \\
\text { prospects for financial institutions and promote } \\
\text { cooperation between banks and enterprises, striving for } \\
\text { loan support. (Broaden financing channels) } \\
\text { A24 The company guides and vigorously promotes } \\
\text { advanced manufacturing modes, such as intelligent } \\
\text { manufacturing, lean manufacturing, and flexible } \\
\text { manufacturing, and seeks to use the new generation of } \\
\text { production and manufacturing modes, such as } \\
\text { concurrent engineering, networked manufacturing, and } \\
\text { collaborative manufacturing. (Informatization) }\end{array}$ \\
\hline 16 & $\begin{array}{l}\text { Compatibility of existing } \\
\text { international production } \\
\text { system and green innovation }\end{array}$ & $\begin{array}{l}\text { A7 Enterprises have begun to use information } \\
\text { technology to compete with each other. This competition } \\
\text { tends to be fast, flexible, automatic, and global. The } \\
\text { information technology revolution is changing the } \\
\text { competition modes of enterprises. (Technology change) } \\
\text { A9 A reasonable arrangement of production sites and the } \\
\text { implementation of different management modes are new } \\
\text { ways for enterprises to continuously explore and } \\
\text { improve their economic benefits. (Increasing } \\
\text { competition) }\end{array}$ \\
\hline
\end{tabular}


Table A1. Cont.

\begin{tabular}{|c|c|c|}
\hline Number & Category & Original Data (Initial Material) \\
\hline 17 & $\begin{array}{l}\text { The increase in global green } \\
\text { manufacturing costs }\end{array}$ & $\begin{array}{l}\text { A8 The government issues reasonable low-carbon } \\
\text { standards and strengthens law enforcement. To } \\
\text { implement low-carbon standards, we should treat every } \\
\text { enterprise fairly. If some enterprises which fail to meet } \\
\text { the standards, they should be punished correspondingly. } \\
\text { (Low-carbon emission standards) } \\
\text { A19 In the process of implementing green innovation, } \\
\text { enterprises need to invest considerable human resources } \\
\text { and funds. If the government can provide subsidies for } \\
\text { enterprises at this time, many problems could be solved } \\
\text { for the development of green innovation. (Government } \\
\text { subsidy) } \\
\text { A21 For enterprises using current traditional modes of } \\
\text { production development, income is relatively optimistic. } \\
\text { If the government requires enterprises to reduce their } \\
\text { carbon emissions, then it needs to invest a large amount } \\
\text { of funds for the implementation of green innovation. } \\
\text { (Mandatory rules and regulations) }\end{array}$ \\
\hline 18 & $\begin{array}{l}\text { Proportion of global green } \\
\text { marketing personnel input }\end{array}$ & $\begin{array}{l}\text { A1 Enterprises should invite professionals to organize } \\
\text { marketing personnel training courses regularly. } \\
\text { (Organizational training) } \\
\text { A5 The enterprise provides performance rewards to its } \\
\text { marketing personnel. The sales champion of the week is } \\
\text { selected at the weekly meeting, and the corresponding } \\
\text { material rewards are awarded. (Performance Award) } \\
\text { A13 In the past two years, the company has employed } \\
\text { excellent sales personnel with high salaries, } \\
\text { implementing rich material rewards and development } \\
\text { space. (Introduction of talents) } \\
\text { A16 Enterprises have rich Mid Year Awards every year. } \\
\text { To maintain excellent employees, the company has } \\
\text { implemented corresponding ladder type welfare } \\
\text { treatment. (Prevent the brain drain) }\end{array}$ \\
\hline 19 & $\begin{array}{l}\text { Proportion of global green } \\
\text { marketing investment }\end{array}$ & $\begin{array}{l}\text { A3 Enterprises will regularly invite professionals to give } \\
\text { relevant lectures, thus training their employees. (Talent } \\
\text { training mode) } \\
\text { A12 Due to the commodity sales, business indicators, } \\
\text { and other reasons, it is necessary to achieve the expected } \\
\text { business objectives through various marketing means, } \\
\text { such as advertising, price reduction, bundling, purchases } \\
\text { and gifts, rebates, gift distributions, free trials, and other } \\
\text { marketing means. (Promotional activities) } \\
\text { A15 Enterprises take 3\% off their annual planned } \\
\text { turnover as their marketing capital investment. (Budget } \\
\text { standard) } \\
\text { A18 Formulate a marketing fund use plan, effectively } \\
\text { control all the investment funds, and make full use of } \\
\text { (and determine) the flow direction of each fund. (Fund } \\
\text { use plan) }\end{array}$ \\
\hline
\end{tabular}


Table A1. Cont.

\begin{tabular}{|c|c|c|}
\hline Number & Category & Original Data (Initial Material) \\
\hline 20 & $\begin{array}{l}\text { International demand level } \\
\text { for green products }\end{array}$ & $\begin{array}{l}\text { A7 Now consumers pay more attention to energy } \\
\text { conservation and environmental protection. When they } \\
\text { buy products, they also pay more attention to this aspect } \\
\text { of performance. Therefore, green products represent an } \\
\text { opportunity. (Green market demand) } \\
\text { A12 At present, enterprises offer both traditional } \\
\text { innovative products and new green products. Given the } \\
\text { changing trends of sales in the last three months, the } \\
\text { demand for green products is gradually increasing. } \\
\text { (Demand for green products) } \\
\text { A18 In recent years, the haze problem has become } \\
\text { increasingly more serious, environmental problems are } \\
\text { increasingly focused on by the public, China's per capita } \\
\text { consumption level has improved, and the public's } \\
\text { awareness of low-carbon life is becoming stronger. } \\
\text { (Public awareness of environmental protection) }\end{array}$ \\
\hline 21 & $\begin{array}{l}\text { International market } \\
\text { recognition of green } \\
\text { products in the } \\
\text { manufacturing industry }\end{array}$ & $\begin{array}{l}\text { A3 Using the results of the customer's purchase } \\
\text { information feedback, the company's new green } \\
\text { products can better meet the needs of consumers than } \\
\text { the original traditional innovative products. (Consumer } \\
\text { satisfaction) } \\
\text { A4 To improve public awareness of environmental } \\
\text { protection, the news media actively report and promote } \\
\text { the concept of green innovation. (Media publicity) } \\
\text { A11 Increasingly more consumers tend to buy green } \\
\text { products when they buy products, and their awareness of } \\
\text { energy conservation and emission reduction is becoming } \\
\text { stronger. (Environmental awareness of consumers) } \\
\text { A14 In recent years, the emergence of green products, } \\
\text { such as electric vehicles and wind power generation, has } \\
\text { embodied enterprises' R\&D, and managers are paying } \\
\text { more attention to the green development of enterprises. } \\
\text { (Green development strategy) }\end{array}$ \\
\hline 22 & $\begin{array}{l}\text { International market share of } \\
\text { green products }\end{array}$ & $\begin{array}{l}\text { A1 The international competitiveness of an industry is } \\
\text { ultimately reflected in the share of its products in the } \\
\text { international market. (International market share) } \\
\text { A3 The company adheres to the business philosophy of } \\
\text { focusing on foreign trade supplemented by domestic } \\
\text { trade, continuously expanding its market share in the } \\
\text { international market; the market in China is also } \\
\text { increasing. (Expanding market share) } \\
\text { A10 Teamwork develops the international market; at the } \\
\text { same time, it expands the international market share and } \\
\text { gradually establishes a company image of "quality first, } \\
\text { service first". (Developing international market) }\end{array}$ \\
\hline 23 & $\begin{array}{l}\text { Competition intensity of } \\
\text { green products in the } \\
\text { international market }\end{array}$ & $\begin{array}{l}\text { A6 Now, the profits of traditional BX products have been } \\
\text { squeezed to their limits, and other competitors have } \\
\text { begun to save energy. Low energy consumption } \\
\text { products are a bright spot when looking for new } \\
\text { business opportunities, but they will be gradually } \\
\text { eliminated if they do not transform in time. (Fierce } \\
\text { market competition) } \\
\text { A9 When enterprises hold a seminar, they mention that } \\
\text { they should regard green innovation from a strategic } \\
\text { perspective. Managers always remind employees that } \\
\text { green innovation has become the development trend of } \\
\text { the whole industry. (Industry development trend) }\end{array}$ \\
\hline
\end{tabular}


Table A1. Cont.

\begin{tabular}{|c|c|c|}
\hline Number & Category & Original Data (Initial Material) \\
\hline 24 & $\begin{array}{l}\text { Green products' share of } \\
\text { existing international } \\
\text { marketing channels }\end{array}$ & $\begin{array}{l}\text { A7 The international market for manufacturing green } \\
\text { products (processes, services) requires changes; its } \\
\text { recognition is not high enough, and the international } \\
\text { market share of manufactured green products (processes, } \\
\text { services) is too small. Moreover, international market } \\
\text { competition is fierce, and it is difficult to use existing } \\
\text { international marketing channels. (International market } \\
\text { channel) } \\
\text { A13 The high proportion of existing marketing channels } \\
\text { is an important area for the success of new product } \\
\text { marketing. (Marketing Channel) }\end{array}$ \\
\hline
\end{tabular}
marketing. (Marketing Channel)

A1 Since entering the 21st century, international management has become the future development goal of enterprises; this will be the result of the rapid development of economic globalization and production internationalization. (International operation) A11 We investigated the internationalization degree of chess enterprises at the micro level, including the

Commercialization and internationalization of green technology financing ability, asset utilization ability, internationalization of science and technology enterprises, technological innovation ability, and human capital. (Degree of internationalization)

A17 After the development of recent years, the commercialization, industrialization, and internationalization of green technology of our enterprises have made great progress.

(Commercialization and internationalization of green technology)

A6 Technical barriers to trade (TBTs) are the most effective means to establish trade barriers and promote trade protectionism. (Trade protection)

A16 Many countries have formulated a series of laws and regulations on their packaging and labeling to prevent the waste generated by packaging machinery from posing a threat to the ecological environment, human beings, animals, and plants. From the perspective of environmental protection and energy conservation, this has a positive effect, but it forces the exporters to change their packaging constantly, so they lose many trade opportunities. (Label rules)

A1 Our service staff are all undergraduates or above. They have a strong sense of customer service and good communication skills. (Staff requirements)

A8 After-sales service is actually the beginning of the second stage of sales. After-sales service personnel positions are specifically set up by the marketing department to serve the last link of marketing. (After-sales service personnel)

A12 We seek excellent talents in domestic and foreign markets, introduce a large number of high-level talents that can guide the development of enterprises, and recruit excellent graduates from major universities across the country to facilitate large-scale talent introduction. (Talent introduction) 
Table A1. Cont.

\begin{tabular}{|c|c|c|}
\hline Number & Category & Original Data (Initial Material) \\
\hline 28 & $\begin{array}{l}\text { Proportion of global green } \\
\text { service investments }\end{array}$ & $\begin{array}{l}\text { A2 The enterprise's annual service capital investment } \\
\text { accounts for more than } 10 \% \text { of the total sales revenue. } \\
\text { (Service investment) } \\
\text { A7 Since last year, we have increased a part of our funds } \\
\text { in after-sales services, which are used for product } \\
\text { installation, introduction, debugging, customer training, } \\
\text { loss reporting, and maintenance for a period of time after } \\
\text { sales. (Service fee) } \\
\text { A16 The percentage control method of the after-sales } \\
\text { service cost refers to the percentage of each after-sales } \\
\text { service cost in terms of sales volume. This percentage } \\
\text { can be based on the current amount in the budget or that } \\
\text { in the past. (Percentage control method) }\end{array}$ \\
\hline
\end{tabular}

A3 The after-sale service outlets of the enterprise are all above the prefecture-level cities in China. In the next three years, the enterprise will strive to increase the number of its after-sale service outlets in county-level cities. (After-sale service outlets) $29 \begin{gathered}\text { Coverage of global green } \\ \text { service outlets }\end{gathered}$
A5 The enterprise will provide tracking services, that is, a regular follow-up or telephone follow-up. These follow-ups will solve all kinds of problems found by users in the process of use and avoid further deterioration of the problems. (Tracking service) A6 The enterprise will place spare equipment in the after-sale outlet according to the situation. Users can use this equipment when accidents occur to not affect the normal work of users. (Spare equipment service)

A2 In the background of economic globalization, the level of the national supply chain determines its resource allocation ability, coordination, and service support. Especially in the process of promoting "one belt, one road" construction, we need to improve our overall planning capabilities by improving the level of the supply chain. (The level of the supply chain) A20 The integration ability of the supply chain and collaborative efficiency have become the core areas of competitiveness in enterprises, industries, and even the national economy. (The integration and collaboration of the supply chain)

A4 The system service ability of the enterprise is very strong. It has an experienced engineering service team that can provide after-sale and engineering services, and they can quickly solve on-site problems. (Service ability) A6 The enterprise arranges technical personnel to introduce the product function to the users before delivery. After delivery, these personnel conduct centralized training for users. This training service will ensure that users are fully aware of and familiar with the operation of the products, even allowing them to carry out simple maintenance themselves. (Operation instruction)

A12 The enterprise requires after-sale service staff to fill in the maintenance report promptly after a repair. The maintenance report should include the cause of the failure, the handling situation, and the user's opinions. Each party retains one copy of the maintenance report as a record. (Maintenance report)

Note: A* refers to the (first/second and so on) interviewee's interview materials. The brackets at the end of each sentence are the initial concepts. 


\section{References}

1. Tong, J.D.; Xie, D.Y.; Bao, Q.; Huang, Q.H.; Li, X.Y.; Liu, Z.B.; Jin, B.; Yu, M.J.; Wang, X.S. “Anti Globalization” and the Transformation and Upgrading of the Real Economy. Chin. Ind. Econ. 2017, 6, 5-59.

2. Zhang, F.; Gallagher, K.S. Innovation and technology transfer through global value chains: Evidence from china's pv industry. Energy Policy 2016, 94, 191-203. [CrossRef]

3. Yin, S.; Zhang, N.; Li, B.Z.; Dong, H.M. Enhancing the effectiveness of multi-agent cooperation for green manufacturing: Dynamic co-evolution mechanism of a green technology innovation system based on the innovation value chain. Environ. Impact Assess. Rev. 2021, 86, 106475. [CrossRef]

4. Müller, J.M.; Voigt, K.I. Sustainable industrial value creation in SMEs: A comparison between industry 4.0 and made in China 2025. Int. J. Precis. Eng. Manuf. Green Technol. 2018, 5, 659-670. [CrossRef]

5. Saunila, M.; Ukko, J.; Rantala, T. Sustainability as a driver of green innovation investment and exploitation. J. Clean. Prod. 2018, 179, 631-641. [CrossRef]

6. Gupta, H.; Barua, M.K. A grey DEMATEL-based approach for modeling enablers of green innovation in manufacturing organizations. Environ. Sci. Pollut. Res. 2018, 25, 9556-9578. [CrossRef] [PubMed]

7. Köhler, A.R.; Som, C. Risk preventative innovation strategies for emerging technologies the cases of nano-textiles and smart textiles. Technovation 2014, 34, 420-430. [CrossRef]

8. Song, M.; Fisher, R.; Kwoh, Y. Technology challenges of green innovation and sustainable resource management with large scale data. Technol. Forecast. Soc. Chang. 2019, 144, 361-368. [CrossRef]

9. Meroño-Cerdán, A.L.; López-Nicolás, C.; Molina-Castillo, F.J. Risk aversion, innovation and performance in family firms. Econ. Innov. New Technol. 2018, 27, 189-203. [CrossRef]

10. Mercado-Caruso, N.; Segarra-Oña, M.; Ovallos-Gazabon, D.; Peiró-Signes, A. Identifying Endogenous and Exogenous Indicators to Measure Eco-Innovation within Clusters. Sustainability 2020, 12, 6088. [CrossRef]

11. Bernauer, E.; Kammerer, S. Explaining Green Innovation. In Center for Comparative and International Studies; Working Paper; University of Zurich: Zurich, Switzerland, 2006; pp. 1-16. [CrossRef]

12. Gang, Z.; Zhang, X.J. Review and Prospect of foreign green innovation research. Foreign Econ. Manag. 2011, 33, 25-32.

13. Zhao, Y. Innovation Economics; China Economic Press: Beijing, China, 2006; p. 30.

14. Otway, H.J.; Von Winterfeldt, D. Beyond acceptable risk: On the social acceptability of technologies. Policy Sci. 1982, 14, 247-256. [CrossRef]

15. Sun, Y.Y.; Bi, K.X.; Yin, S. Measuring and integrating risk management into green innovation practices for green manufacturing under the global value chain. Sustainability 2020, 12, 545. [CrossRef]

16. George, C.; Hartmann, M.; Mvers, B. Technical Risk, Produet Specifications and Market Risk; The MIT Press: Cambridge, MA, USA, 2003; pp. 178-186. Available online: https://www.mendeley.com/catalogue/5b79699dfaa5-3bd7-81ca-715b44c8e433/ (accessed on 17 November 2020).

17. George, S.D.; Shoemaker, P.J.H. Wharton on Managing Emerging Technologies; Xuaxia Publishing House: Beijing, China, 2002; pp. 185-190.

18. Peter, L. The importance of integtating risk in retrospective evaluations of research and development. Res. Eval. 2012, 21, 152-165.

19. Miorando, R.; Ribeiro, J.L.D.; Cortimiglia, M.N. An economic-probabilistic model for risk analysis in technological innovation projects. Technovation 2014, 34, 485-498. [CrossRef]

20. Gong, C. Risk Management and Risk Sharing of Scientific and Technological Innovation. Chin. Mark. 2011, $29,27$.

21. Fan, H.; Xu, X. Risk Analysis of Technological Innovation. Innov. Entrep. Manag. 2017, 2, 1-10.

22. Yang, C.; Bi, K.; Hu, R. Transmission Mechanism of Green Innovation Power of Industrial Enterprises in an Open Economy. Syst. Eng. 2018, 36, 79-90.

23. Horbach, J.; Rammer, C.; Rennings, K. Determinants of eco-innovations by type of environmental impact-The role of regulatory push pull, technology push and market pull. Ecol. Econ. 2012, 78, 112-122. [CrossRef]

24. El-Kassar, A.N.; Singh, S.K. Green innovation and organizational performance: The influence of big data and the moderating role of management commitment and HR practices. Technol. Forecast. Soc. Chang. 2019, 144, 483-498. [CrossRef] 
25. Fernando, Y.; Jabbour CJ, C.; Wah, W.X. Pursuing green growth in technology firms through the connections between environmental innovation and sustainable business performance: Does service capability matter? Resour. Conserv. Recycl. 2019, 141, 8-20. [CrossRef]

26. Trott, A.H. Innovation risks of strategic outsourcing. Technovation 2006, 26, 672-681.

27. Baryannis, G.; Validi, S.; Dani, S.; Antoniou, G. Supply chain risk management and artificial intelligence: State of the art and future research directions. Int. J. Prod. Res. 2019, 57, 2179-2202. [CrossRef]

28. Ma, X.M.; Li, J. Research on Risk Identification of Harbin Mudanjiang Railway Passenger Dedicated Line Construction Project Based on Fault Tree. Sci. Technol. Manag. 2016, 18, 82-86.

29. Xiaodong, L.; Kexin, B.; Hui, Y. Research on Risk Management of Low Carbon Technology Breakthrough Innovation under Global Value Chain: A Case Study of Chinese Manufacturing Industry. Chin. Soft Sci. 2016, 11, 152-166.

30. Glaser, B.G.; Strauss, A.L. The Discovery of Grounded Theory: Strategies for Qualitative Research; Aldine Publishing Company: Chicago, IL, USA, 1967.

31. Wenhui, Z. Knowledge Service, Value Co-creation and Innovation Performance: A Multi Case Study Based on Grounded Theory. Sci. Res. 2015, 33, 567-573.

32. Zhang, B.; Zhang, Q. Research on Influencing Factors of Members Willingness to Cooperate based on Grounded Theory. J. Manag. 2015, 8, 1224-1229.

33. Goldkuhl, G.; Cronholm, S. Multi-grounded theory-Adding theoretical grounding to grounded theory. Int. J. Qual. Methods 2015, 2, 187-205. [CrossRef]

34. Su, Y.; Wu, N.; Zhou, X. Entrepreneurial Process Model from Institutional Perspective: A Multi Case Study based on Grounded Theory. Nankai Manag. Rev. 2017, 2, 181-192. [CrossRef]

35. Fassinger, R.E. Paradigms, praxis, problems and promise: Grounded theory in counseling psychologyresearch. J. Couns. Psychol. 2005, 52, 156-166. [CrossRef]

36. Xu, Y.; Qi, L.; Lv, X. Identification of Key Drivers of Low Carbon Innovation Performance of Manufacturing Enterprises based on Grounded Theory. Chin. Sci. Technol. Forum 2018, 3, 81-90.

37. Xu, J.; Qu, X. Qualitative Research on Driving Factors of Environmental Technology Innovation Behavior of Equipment Manufacturing Enterprises based on Grounded Theory. Manag. Rev. 2014, 26, 90-101.

38. Yin, B.; Xiao, W.; Liu, Y. Green R\&D investment and the Rise of "made in China" in Global Value Chain. Sci. Res. 2018, 36, 1395-1403.

39. Wu, D.D.; Kefan, X.; Hua, L. Modeling technological innovation risks of an entrepreneurial team using system dynamics: An agent-based perspective. Technol. Forecast. Soc. Chang. 2010, 776, 857-869. [CrossRef]

40. $\mathrm{Wu}, \mathrm{J} . ; \mathrm{Wu}, \mathrm{Z}$. Integrated risk management and product innovation in China: The moderating role of board of directors. Technovation 2013, 11, 1-11. [CrossRef]

41. Su, Y.; Li, T.C. Simulation analysis of knowledge transfer in a knowledge alliance based on a circular surface radiator model. Complexity 2020, 2020, 4301489. [CrossRef]

42. Gao, X.; Ye, H.; Kang, Y. Research on Enterprise Technology Innovation Risk Management based on Risk Matrix. Sci. Technol. Manag. Res. 2014, 34, 8-11.

43. Lu, X. Enterprise's Low Carbon Innovation Collaborative Model based on Urban Green Transformation. Sci. Technol. Prog. Countermeas. 2015, 4, 67-71.

44. Chen, Y.; Liu, J.; Xie, K. Risk in integrated leapfrogging mode of technological innovation. Kybernetes 2012, 4110, 1423-1439. [CrossRef]

45. Mao, J.; Huo, B. Risk and Evaluation of Technological Innovation. Research on Quantitative Economy. Technol. Econ. 2002, 2, 1-5.

46. Yin, S.; Zhang, N.; Li, B. Improving the Effectiveness of Multi-Agent Cooperation for Green Manufacturing in China: A Theoretical Framework to Measure the Performance of Green Technology Innovation. Int. J. Environ. Res. Public Health 2020, 17, 3211. [CrossRef] [PubMed]

47. Xiao, T.; Liu, H.; Ye, P. Research on the Influencing Factors of Service Innovation of Manufacturing Enterprises. J. Manag. 2014, 4, 591-598. 
48. Jiang, G. On the Relationship between After-Sales Technical Support and After-Sales Technical Support and Customer Satisfaction. Silicon Val. 2013, 1, 159-181.

49. Yin, S.; Zhang, N.; Dong, H.M. Preventing COVID-19 from the perspective of industrial information integration: Evaluation and continuous improvement of information networks for sustainable epidemic prevention. J. Ind. Inf. Integr. 2020, 19, 100157. [CrossRef]

Publisher's Note: MDPI stays neutral with regard to jurisdictional claims in published maps and institutional affiliations.

(C) 2020 by the authors. Licensee MDPI, Basel, Switzerland. This article is an open access article distributed under the terms and conditions of the Creative Commons Attribution (CC BY) license (http://creativecommons.org/licenses/by/4.0/). 